\title{
Artikel
}

\section{Branded, co-packing of private label: slechts een kwestie van smaak?}

\author{
Felix Roscam Abbing*
}

In dit artikel wordt een overzicht gegeven van de overwegingen die ten grondslag liggen aan de marktafbakening bij de productie van eigen merk (branded), co-packing (merk van een derde) en private label (huismerk). Hierbij zullen zaken en kernoverwegingen uit de beschikkingspraktijk van de Europese Commissie, de ACM en de Britse mededingingsautoriteit CMA worden besproken. Het artikel spitst zicht toe op overwegingen voor het upstream (productie)niveau aan de hand van beschikkingen inzake, met name, levensmiddelen.

\section{Inleiding}

Steeds minder vaak worden fast moving consumer goods en levensmiddelen geproduceerd door de bedrijven die ze bedenken en ontwikkelen; het produceren van branded (eigen merk) producten. Het outsourcen van de productie wordt steeds belangrijker, en daarmee ook het produceren op contractbasis voor een derde merkhouder: oftewel co-packing of contract manufacturing (hierna zal dit worden aangeduid als co-packing).

Het produceren van producten voor derden kwam al vaak voor in het kader van de producent-retailerverhouding. De verschillende huismerkproducten - oftewel private label - van supermarkten worden doorgaans geproduceerd door derden met - doorgaans - de receptuur van de producent (waarbij de klant vaak bepaalde voorkeuren aangeeft, bijvoorbeeld inzake verpakking,

Mr. F.A. Roscam Abbing is werkzaam als advocaat bij Freshfields Bruckhaus Deringer. Dit artikel is geschreven op persoonlijke titel. De auteur dankt Erik Pijnacker Hordijk voor de zeer interessante discussies over dit onderwerp en met name Friesland/Campina en de achtergrondinformatie bij de Bolletje-zaak. kwaliteit, ingrediënten, enzovoort). Naast de productie door derden van privatelabelproducten en merkproducten via co-packing, zijn er nog steeds ondernemingen die hun eigen producten bedenken, ontwikkelen en ook produceren.

Er zijn uiteraard ook partijen actief die verschillende combinaties (bijvoorbeeld private label en co-packing) of alles (inclusief ook eigen merk voeren) doen. Zo produceert en verkoopt een van 's werelds grootste bottelaars, Refresco, ook dranken onder eigen merk, de 'Wicky-dranken', terwijl het ook produceert (c.q. heeft geproduceerd) voor retailers (Tesco, Lidl, Aldi, Plus) en A-merken als Innocent Smoothies, Pepsi en Lipton. ${ }^{1}$

Bij de beoordeling van met name fusies en overnames (maar het kan uiteraard ook buiten het concentratietoezicht een rol spelen) komt de vraag op of de productie van branded en private label, en (steeds vaker) co-packing, met elkaar concurreert en tot dezelfde markt behoort. De beschikkingspraktijk van de verschillende nationale mededingingsautoriteiten en de Europese Commissie (hierna: Commissie) is logischerwijs sterk casuïstisch. Behoren alle drie de productieactiviteiten tot één en dezelfde markt? Zijn er drie verschillende markten, of bestaan er verschillende combinaties van markten afhankelijk van het product en de concurrentiesymmetrie? Hoe verhoudt de concurrentie op het upstreamniveau zich met de (indirecte) concurrentiedruk uit het downstreamniveau?

In dit artikel wordt een overzicht gegeven van de overwegingen die ten grondslag liggen aan de marktafbakening bij de productie van eigen merk (branded), copacking (merk van een derde) en private label (huismerk). Hierbij zullen beschikkingen en kernoverwegingen uit de praktijk van de Europese Commissie, de

1. 'Producent van Wicky naar de beurs', de Volkskrant 3 maart 2015. 
Autoriteit Consument \& Markt (ACM), ${ }^{2}$ en de Competition and Markets Authority (CMA) ${ }^{3}$ worden besproken. Het artikel spitst zicht toe op overwegingen voor het upstream(productie)niveau aan de hand van beschikkingen inzake, met name, levensmiddelen.

\section{Branded}

In dit artikel zal worden verwezen naar branded als het gaat om de productie (en ontwikkeling) van eigen merkproducten. Bij branded produceert, ontwikkelt en verkoopt een producent voor eigen rekening en risico. Een voorbeeld hiervan is het broodbeleg van De Ruijter (onderdeel van de Kraft Heinz groep) dat door Kraft Heinz wordt bedacht, ontwikkeld, gemarket en - sinds kort wederom - geproduceerd. ${ }^{4}$ In dit geval is de producent ook de verkoper van het product aan het retailkanaal.

\section{Private label}

Privatelabelproducten worden geproduceerd door een derde producent die deze producten niet zelf voor eigen rekening en risico op de markt brengt. De marketing van het product (en het 'merkeigendom') van deze privatelabelproducten ligt bij de retailer. De retailer betaalt dus voor de productie, maar neemt zelf de marketing en positionering van het (huis)merk voor zijn rekening. Overigens worden de meeste privatelabelproducten in het assortiment opgenomen en gebaseerd op reeds bestaande merkproducten (het is in feite een 'me too' product; of zoals omschreven door de Commissie: 'private label usually "piggy-back" on manufacturer led innovation'5). Privatelabelproducten kunnen worden geproduceerd volgens de receptuur van de producent of de klant (bijvoorbeeld op grond van het recept van een retailer). Een voorbeeld van een privatelabelproduct is het bier van Albert Heijns huismerk: 'Brouwers'. Dit bier wordt geproduceerd door Grolsch. ${ }^{6}$

\section{Co-packing}

Bij co-packing worden (A-)merkproducten door een derde partij voor rekening en risico van een merkhouder geproduceerd. De merkhouder is eigenaar van het merk, het recept, neemt de ontwikkeling en marketing van het product op zich en verkoopt direct aan retailers. Aan het besluit om voor co-packing te kiezen kunnen verschillende redenen ten grondslag liggen. Zo kan co-packing aantrekkelijk zijn voor producten die in zeer substantiële kwantiteiten moeten worden geproduceerd en dienen te worden verspreid over de hele wereld, maar kan het juist ook antrekkelijk zijn indien (zeer) kleine hoeveelheden van het product moeten worden vervaardigd. In dergelijke gevallen is het vaak aantrekkelijker voor een merkeigenaar om de producten te laten produceren via co-packing dan productiefaciliteiten te openen en zelf de producten te produceren. De rol van de co-packers is doorgaans beperkt tot het produceren van producten op basis van het recept (en productiemethode), ontwerp en gewenste verpakking van een merkhouder, maar ook hier zijn verschillende smaken mogelijk, afhankelijk van de wens van de klant en de capaciteiten van de producent.

Een voorbeeld van co-packing zijn de (mosterd)sauzen van Maille die door Pauwels Sauces worden geproduceerd. Daarnaast produceert Pauwels Sauces zowel branded sauzen (Pauwels Mayonaise), privatelabelsauzen en sauzen voor internationale A-merken (copacking). ${ }^{7}$

Bij co-packing is de producent niet de verkoper van het product aan het retailkanaal en heeft de producent ook geen relatie met de retailer. ${ }^{8}$

\section{Private label en branded: kernoverwegingen ten grondslag aan marktafbakening}

De marktafbakening voor de productie van private label en branded is sterk casuistisch waardoor er zowel zaken zijn waarin één relevante markt voor de productie van
2. In dit artikel zal voor de consistentie steeds naar de 'ACM' worden verwezen, terwijl dit ook betrekking kan hebben op haar voorganger, de Nederlandse Mededingingsautoriteit (NMa).

3. De Britse mededingingsautoriteit, Competition and Markets Authority (CMA). In dit artikel zal voor consistentie steeds naar 'CMA' worden verwezen, terwijl dit ook betrekking kan hebben op haar voorgangers, de Office of Fair Trading (OFT) of de Competition Commission (CC).

4. 'Kraft Heinz redt hagelslag en limonadesiroop', De Telegraaf 14 mei 2019.

5. Besluit Commissie 8 mei 2000, zaak COMP/M.1892 (Sara Lee/Courtaulds), punt 18

6. www.rtlz.nl/business/artikel/4226581/de-geheime-wereld-achterhuismerkbier-van-supermarkten.
7. Zie www.pauwels-sauces.com/nl/over-ons/.

8. Overigens bestaan er wel modellen waar de producent ook direct levert aan retailers op verzoek van de merkhouder. De onderhandelingen, marketing en prijsvoering blijven echter van de producten bij de merkeigenaar. 
private label en branded wordt afgebakend ${ }^{9}$ alsook waarin aparte relevante markten worden afgebakend voor de productie van private label en branded. ${ }^{10} \mathrm{Dit}$ is ook logisch aangezien de concurrentiële context in veel zaken sterk zal verschillen.

Er zijn echter wel een aantal kernoverwegingen die ten grondslag liggen aan de marktafbakening en die (zouden moeten) worden toegepast op de concurrentiële context van elke zaak.

Zo wordt systematisch een onderscheid gemaakt tussen het upstreamniveau, waar de desbetreffende producten worden afgenomen door retailers, horeca en/of industriële partijen (en waar dus concurrentie plaatsvindt tussen producenten en leveranciers), en de downstreammarkt waar de verkoop aan consumenten plaatsvindt en er dus concurrentie plaatsvindt voor de verkoop van de producten aan de consument.

Binnen het upstream niveau kunnen vervolgens - afhankelijk van de concurrentiële context van de zaak - nadere onderscheiden worden gehanteerd tussen verschillende afzetkanalen. Reeds in de Unilever/ Amora-Maille- en Unilever/Bestfoods-besluiten uit $2000^{11}$ hanteerde de Commissie een onderscheid tussen de productie van levensmiddelen voor het retailkanaal en het food services-kanaal ${ }^{12}$ (door de ACM vaker genoemd het out of home-kanaal $\left.{ }^{13}\right)$. In andere zaken was nog een derde afzetkanaal relevant: voor industriële

9. Zie o.a. Commissiebeschikkingen: besluit 7 september 2015, zaak COMP/M.7625 (ADM/AOR); besluit 8 mei 2000, zaak COMP/M.1892 (Sara Lee/Courtaulds); en besluit 16 januari 1996, zaak COMP/M.623 (Kimberly-Clark/Scott Paper. ACM-beschikkingen: zie o.a. besluit 14 september 2012, zaak 7313 (NPM Capital - Lion Capital - Buitenfood - Ad van Geloven); besluit 20 april 2007, zaak 5703 (Cosun CSM); besluit 24 april 2006, zaak 5476 (PepsiCo - Duyvis); besluit 29 november 2005, zaak 5265 (NPM - Hak); en besluit 22 september 2003, zaak 3624 (Zwanenberg Food Group - Cebeco Meat Products). En CMA-beschikkingen: zie o.a. besluit 11 juli 2018, zaak ME/6737/18 (Arla Foods/Yeo Valley Dairies); besluit 20 april 2017, zaak ME/ 6675/17 (Hain Frozen Foods/Yorkshire Provender Limited); besluit 6 oktober 2014, zaak ME/6452/14 (Associated British Foods/Dorset Cereals); besluit 26 september 2012, zaak ME/5589/12 (Nakano UK Holding/Premier Foods Group); besluit 5 mei 2009, zaak ME/4033/09 (Dr. Oetker Group/Schwan's Group).

10. Zie o.a. Commissiebeschikkingen: besluit 15 mei 2013, zaak COMP/M. 6981 (Agrofert/Lieken); besluit 13 januari 2012, zaak COMP/M.6321 (Buitenfood/Ad van Geloven Holding/JV); besluit 30 september 2010, zaak COMP/M.5958 (GS/TPG/Ontex); besluit 17 december 2008, zaak COMP/M.5046 (Friesland/Campina); besluit 5 september 2007, zaak COMP/M.4533 (SCA/P\&G); en besluit 31 januari 2001, zaak COMP/ M.2097 (SCA/Metsä Tissue). ACM-beschikkingen: besluit 17 februari 2006, zaak 5499 (Ad van Geloven - Mora); besluit 2 mei 2001, zaak 2434 (Wessanen - Zonnatura); besluit 19 september 2000, zaak 2047 (Van Dijk - Van den Bergh); besluit 13 september 2000, zaak 2033 (Van Dijk - Brinkers). En CMA-beschikkingen: besluit 5 december 2018, zaak ME/6772/18 (Valeo Foods/Taurus 3); besluit 9 juli 2013, zaak CC (AG BARR/Britvic); en besluit 28 november 2005, zaak ME/ 1954/05 (Cott Beverages/Macaw).

11. Besluit Commissie 8 maart 2000, zaak COMP/M.1802 (Unilever/Amora-Maille) en besluit Commissie 28 september 2000, zaak COMP/M. 1990 (Unilever/Bestfoods).

12. Besluit Commissie 28 september 2000, zaak COMP/M.1990 (Unilever/ Bestfoods), punt 8.

13. Zie bijv. besluit Commissie 17 februari 2006, zaak 5499 (Ad van Geloven-Mora), punt 17; en besluit 11 augustus 2005, zaak 5132 (BiezeCelavita), punt 17-18 afnemers (die de producten als input gebruiken om zelf verdere producten te maken).

Een goed voorbeeld van een zaak waar de Commissie deze verschillende kanalen analyseerde en overwoog is de $M_{c}$ Cain/Lutosa-zaak. ${ }^{14}$ In het kader van de concurrentiële context van de zaak (McCain en Lutosa waren beide actief in de productie van aardappelproducten - bevroren, gekoeld en gedehydrateerd - zoals frietjes ${ }^{15}$ ) overwoog de Commissie dat er drie verschillende afzetkanalen konden worden geidentificeerd met daarbinnen nog een nadere segmentering (zowel naar type afnemer als type product): ${ }^{16}$

1. Het food services kanaal, te onderscheiden naar:

a. het quick service restaurants-kanaal (fastfoodrestaurants zoals McDonalds) zonder nader onderscheid naar type product;

b. het overige food services-kanaal (horeca, bedrijfsrestaurants enz.), met een nader onderscheid naar:

i. bevroren of gekoelde aardappelproducten;

ii. frietjes en overige specialiteitsproducten (bijv. wedges, pommes duchesse enz.);

iii. premium en niet-premium bevroren aardappelproducten;

2. Het retailkanaal (supermarkten en overige (levensmiddelen)winkels) met een nader onderscheid naar:

a. bevroren, gekoelde of gedehydrateerde aardappelproducten;

b. frietjes en overige specialiteitsproducten; en

c. private label en branded;

3. het industriekanaal (bedrijven die de aardappelproducten inkochten om vervolgens te verwerken tot kant-en-klare maaltijden of andere aardappelproducten zoals chips of gnocchi):

Binnen elk van deze kanalen werd, voor zover relevant, overwogen of private label met branded concurreert. Met betrekking tot het overige food service-kanaal overwoog de Commissie dat branded en privatelabelproducten tot één gedifferentieerde relevante markt behoorden. In het retailkanaal oordeelde de Commissie dat diezelfde privatelabel- en branded producten wel tot aparte relevante markten behoorden. In haar analyse nam de Commissie in overweging of, op het upstreamniveau, branded en private label substitueerbaar of juist complementair werden beschouwd door retailers (of retailers dus in het geval van een prijsverhoging voor branded, zouden switchen naar (meer) private label).

14. Besluit Commissie 28 mei 2013, zaak COMP/M.6981 (McCain Foods Group/Lutosa Business).

15. In de originele Engelse versie van het besluit wordt naar 'French fries' verwezen (met hoofdletter F). Hiermee lijkt de Commissie aan te geven dat frietjes een Frans element of Franse oorsprong hebben. In dit artikel wordt verwezen naar frietjes of friet, daar deze auteur begrijpt dat de oorsprong van 'French fries' ligt in het oud-Engelse werkwoord 'to french' wat simpelweg betekent in lange dunnen reepjes snijden (vgl. julienne) en dus geen verband houdt met het land Frankrijk. Het is bij de auteur niet bekend hoe McCain of Lutosa hierover denken.

16. Besluit Commissie 28 mei 2013, zaak COMP/M.6981 (McCain Foods Group/Lutosa Business), punt 14. 
Zo verwees de Commissie naar Friesland/Campina ${ }^{17}$ waarin zij oordeelde dat voor verse melk en houdbare melk branded en private label met elkaar concurreerden in dezelfde relevante markt, maar dat voor overige zuivelproducten (desserts of andere dranken zoals chocolademelk) branded en private label niet tot één en dezelfde relevante markt behoorden maar juist tot aparte relevant markten. Dit kwam vanwege merkloyaliteit en (mede daardoor) de perceptie van retailers dat bepaalde merken 'must have' zijn. In McCain/Lutosa overwoog de Commissie dat in tegenstelling tot de melkmarkten in Friesland/Campina, er alleen privatelabelproducten voor bevroren frietjes of specialiteitsproducten zijn in het lageprijssegment waardoor er verminderde concurrentiedruk uitgaat op branded producten. Daarnaast vond een meerderheid van de ondervraagde retailers dat zowel McCain als Lutosa must have-merken waren, waardoor deze producten zeer lastig zijn te vervangen door privatelabelalternatieven.

Wat betreft substitutie vanuit de anbodzijde overwoog de Commissie (in lijn met Friesland/Campina) dat indien het gros van zowel privatelabel- als branded producten door dezelfde bedrijven wordt geproduceerd, kan worden aangenomen dat zij rekening houden met de substitueerbaarheid van privatelabel- en branded producten bij de eindklant (de consument). Aangezien zowel McCain als Lutosa (beperkt) actief was in private label en juist andere marktspelers zich volledig hadden toegespitst op de productie van private label, was de concurrentie tussen producenten van branded en private label in het retailkanaal binnen het upstreamniveau asymmetrisch: eerstgenoemden kunnen concurrentiedruk uitoefenen op laatstgenoemden, maar niet andersom. Daarnaast waren de marges voor branded producten ook hoger dan voor private label. Daarom hadden producenten van branded producten slechts een prikkel om ook private label te produceren enkel om hun overcapaciteit te gebruiken.

In Friesland/Campina gaf de Commissie aan dat er met name twee elementen moeten worden beoordeeld om vast te stellen of privatelabel- en branded producten upstream met elkaar concurreren: (1) of private label en branded doorgaans met elkaar concurreren vanuit het perspectief van de eindconsument (met andere woorden indirecte concurrentiedruk uit de downstreammarkt); en (2) de mate waarin upstream door producenten en afnemers rekening wordt gehouden met de concurrentiedruk van privatelabel- op branded producten en vice versa. ${ }^{18}$ Daarnaast gaf de Commissie aan dat de vraag van retailers in het upstreamniveau een afgeleide is van de vraag van de eindconsument, en retailers daarmee dus rekening houden in het afnemen (en de prijszetting) van privatelabelproducten. ${ }^{19}$

Zo kwam de Commissie uiteindelijk tot verschillende conclusies omtrent marktafbakening en het onderscheid

17. Besluit Commissie 17 december 2008, zaak COMP/M.5046 (Friesland/ Campina).

18. Friesland/Campina, punt 179.

19. Friesland/Campina, punt 180. tussen private label en branded voor de verschillende productcategorieën die door zowel Friesland Foods en Campina werden geproduceerd en geleverd aan het retailkanaal. Bij kazen of (gewone) melk kwam zij bijvoorbeeld tot de conclusie dat private label en branded tot dezelfde markt behoren, terwijl zij bij andere zuiveldranken zoals chocolademelk concludeerde dat er aparte markten bestaan voor privatelabel- en branded producten. Bij bijvoorbeeld bewerkte yoghurt (zoals kwark) liet de Commissie de exacte definitie open, maar overwoog zij wel dat er gemengde signalen waren voor het upstreamniveau. Aan de ene kant was het afnameproces (zoals vrijwel altijd) anders voor privatelabel(tenders) en branded producten (bilaterale onderhandeling), concurreerden private label en merk wel met elkaar downstream, en was er (op twee partijen na) vrijwel symmetrische concurrentie tussen producenten aangezien die allemaal privatelabel- en branded producten verkochten.

Ook in de overige beschikkingspraktijk van de Commissie, maar ook de ACM en CMA, wordt marktafbakening op het punt van private label en branded langs de hierboven geschetste lijnen overwogen waarbij upstream concurrentiesymmetrie en indirecte concurrentiedruk uit het downstream kanaal vaak uitvoerig worden beoordeeld.

\section{Upstream concurrentiesymmetrie?}

In een concentratie bij de ACM inzake oliën en frituurvetten ${ }^{20}$ bestond er weliswaar (enigszins) asymmetrische concurrentie tussen partijen - Van Dijk en Van den Bergh produceerden beide branded producten, maar alleen Van Dijk produceerde ook private label maar overwoog de ACM dat vrijwel alle marktpartijen hadden angegeven dat er overcapaciteit was bij producenten en het daardoor mogelijk was om zonder hoge kosten om te schakelen van de productie van branded naar private label. ${ }^{21}$ Met andere woorden, Van den Bergh zou snel private label kunnen produceren. Overigens lijkt impliciet in deze zaak dat er geen of nauwelijks private label-only-producenten waren (anders zou de afweging inzake restcapaciteit niet doorslaggevend kunnen zijn). De ACM liet uiteindelijk de exacte definitie van de markt in het midden.

Vergelijkbare overwegingen inzake de concurrentiesymmetrie en het gebruik van restcapaciteit/overcapaciteit lagen ten grondslag aan de besluiten van de ACM in Van Dijk-Brinkers, Ad van Geloven-Mora en Vandemoortele/Van Dijk. ${ }^{22}$ Enigszins opmerkelijk is wel de conclusie van de ACM in Vandemoortele /Van Dijk inzake witvetten waarin zij concludeert dat er vanuit de zijde van de producent een grote mate van substitutie bestaat omdat het productieproces voor private label en branded identiek is en er ook geen verschillen in de verpak-

20. Besluit Commissie 19 september 2000, zaak 2047 (Van Dijk - Van den Bergh).

21. Van Dijk - Van den Bergh, punt 17

22. Van Dijk - Brinkers, punt 16-19; besluit Commissie 17 februari 2006 zaak 5499 (Ad van Geloven - Mora), punt 24-28; en besluit Commissie 6 augustus 2010, zaak 6996 (Vandemoortele - Van Dijk). 
king (formaat of anders) bestaat en producenten aangeven dat het overstappen van de productie van producten uit het ene segment naar de productie van het andere segment zeer eenvoudig te bewerkstelligen is zonder grote investeringen in tijd of financiële middelen. Tijdens het marktonderzoek zou een producent zelfs hebben aangegeven binnen één dag te kunnen overschakelen. ${ }^{23}$

Wat de ACM hier (mogelijk) onvoldoende overweegt, is dat het productieproces weliswaar identiek is voor private label en branded, maar de marketing, het productierisico en verkoop tussen de privatelabelproducten en branded producten anders geschiedt. Een overstap van branded naar (deels) private label is weliswaar (zeer) eenvoudig, maar andersom lijkt niet evident. Het duurt doorgaans lang voordat een (nieuw) merk voldoende ingeburgerd is bij consumenten waardoor retailers het ook daadwerkelijk in grote hoeveelheden zouden afnemen. Het opbouwen van merkreputatie is daarnaast duur en niet eenvoudig. Wellicht had dit geen verdere impact op de beoordeling van de concentratie, bijvoorbeeld omdat partijen allebei actief waren in de productie van voornamelijk branded producten, maar zou de ACM dit allicht ook in het besluit hebben kunnen beschrijven.

In de Cott/Macam-zaak ${ }^{24}$ beschreef de CMA dat producenten van branded frisdranken vrijwel nooit hun diensten aanboden om privatelabelproducten te produceren, ofschoon het productieproces identiek is. Gezien het feit dat partijen allebei voornamelijk actief waren in de productie van private label, en dat branded producenten dat niet waren, beoordeelde de CMA de concentratie aan de hand van een aparte markt voor privatelabelfrisdrank. ${ }^{25}$

Indirecte concurrentiedruk uit het

downstreamniveau werkt door op het

upstreamniveau

Naast de analyse van de concurrentiesymmetrie tussen producenten in het upstreamkanaal, kan een beoordeling van indirecte concurrentiedruk uit het downstreamkanaal een oplossing bieden voor de vraag of private label en branded in dezelfde markt concurreren. Indien eindafnemers geen substitueerbaarheid ervaren tussen de branded producten en privatelabelproducten, en er upstream concurrentiesymmetrie bestaat, kan de downstreamanalyse doorslaggevend zijn. Met andere woorden, de vraag upstream is een afgeleide van de vraag downstream waardoor deze vraagsubstitutie ook upstream doorwerkt. Dit geldt niet voor het industriekanaal (daar worden de producten immers ingekocht om te worden verwerkt) en in mindere mate voor het foodservicekanaal (want consumenten weten vaak niet of ze branded of privatelabelproducten consumeren, maar er zijn uitzonderingen (bijv. privatelabel- of branded frisdrank)), maar met name voor het retailkanaal aangezien

23. Vandemoortele - Van Dijk, punt 21-22.

24. Besluit CMA 28 november 2005, zaak ME/1954/05 (Cott Beverages/ Macaw).

25. Cott Beverages/Macaw, punt 10-22. consumenten daar doelbewust een keuze moeten maken tussen het branded of privatelabelproduct.

In een fusie tussen twee producenten van ijs(jes) in het Verenigd Koninkrijk liet de CMA de exacte definitie van de markt open, maar overwoog zij wel aparte markten voor privatelabel- en branded ijs. De focus in het onderzoek en de informatie die partijen hadden aangevoerd lag op de indirecte concurrentiedruk uit het downstreamkanaal die op het upstreamniveau in het retailkanaal doorwerkte. Aangezien er concurrentiesymmetrie bestond tussen partijen (beide produceerden zowel branded als private label), werd met name onderzocht in welke mate er voor eindgebruikers substitutie bestond. Zo werden aanbiedingen en koopgedrag van consumenten (op grond van bijvoorbeeld data van consultancies zoals Kantar ${ }^{26}$ ) overwogen. ${ }^{27}$

In de Pepsico-Duyvis-zaak overwoog de ACM ook met name bewijs inzake de downstreamvraag, aangezien er concurrentiesymmetrie bestond in het upstreamsegment waar partijen beide branded en private label verkochten aan retailers. De ACM oordeelde uiteindelijk dat er sprake was van één upstreammarkt voor de productie en verkoop van zowel branded als privatelabelproducten van hartige snacks. ${ }^{28}$

In de Bolletje-zaak ${ }^{29}$ volgde uit het marktonderzoek van de ACM tijdens de eerste fase dat er aanwijzingen waren dat upstreamproducenten van privatelabelontbijtkoek niet dezelfde kwaliteit konden produceren als de branded producenten. Ook bleek dat er nauwelijks mogelijkheden waren om aanpassingen ten aanzien van de kwaliteit van de ontbijtkoek aan te brengen bij deze producenten. ${ }^{30}$ In haar tweedefaseonderzoek in Bolletje concludeerde de ACM uiteindelijk dat er in het besluit zou worden uitgegaan van een markt voor de productie en verkoop van beschuit via het retailkanaal gelet op

'(i) de substitutie tussen private label beschuit en merkbeschuit downstream, en (ii) het feit dat producenten van private label beschuit en/of merkbeschuit alsmede retailers in hun onderhandeling upstream rekening houden met concurrentie tussen private label beschuit en merkbeschuit downstream (...).'31

Tegen dit besluit werd beroep ingesteld bij de Rechtbank Rotterdam, die de ACM in het gelijk stelde. Zij vond ook dat geen nader onderscheid gemaakt diende te worden in het retailkanaal tussen branded en privatelabelproducten. ${ }^{32}$ In hoger beroep vernietigde het College van Beroep voor het bedrijfsleven $(\mathrm{CBb})$ zowel de uitspraak van de rechtbank alsook het besluit van de ACM. ${ }^{33}$ In het kort onderbouwt de ACM volgens het

7. Besluit CMA 1 juli 2013, zaak ME/6020/13 (R\&R Ice Cream/Fredericks Dairies).

28. Besluit ACM 24 april 2006, zaak 5476 (PepsiCo - Duyvis).

29. Besluit ACM 17 april 2012, zaak 7321 (Continental Bakeries - A.A. ter Beek).

30. Continental Bakeries - A.A. ter Beek, punt 27

31. Continental Bakeries - A.A. ter Beek, punt 63.

32. Rb. Rotterdam 27 februari 2014, ECLI:NL:RBROT:2014:1323

33. CBb 11 februari 2016, ECLI:NL:CBB:2016:23. 
College onvoldoende dat, wanneer als gevolg van substitutie op het downstreamniveau van de markt op het upstreamniveau van de markt in het retailkanaal sprake is van één markt voor de productie en verkoop via het retailkanaal, die zowel branded als privatelabelproducten omvat. ${ }^{34}$ Voor een gedetailleerde analyse van deze zaak, zie de annotatie van Theon van Dijk. ${ }^{35}$

Zowel de ACM als de Commissie diende in de kroketten-Zaken ${ }^{36}$ te beoordelen of er een nader onderscheid tussen private label en branded bevroren snacks (zoals kroketten) bestond in het upstreamsegment. De Commissie oordeelde dat branded en privatelabelproducten tot aparte markten behoorden waarbij zij wel enige mate van concurrentiedruk op elkaar uitoefenden. ${ }^{37}$ Uit het marktonderzoek van de Commissie bleek dat de consument wel enige mate van substitueerbaarheid zag tussen private label en branded bevroren snacks, maar dat private label niet de volledige vraag naar branded producten kon vervangen. Naar aanleiding van effectieve marketingcampagnes (wie kent 'Mmmmm van Mora' niet?) en de 'emotionele betrokkenheid' van consumenten bleek dat er een aparte vraag bestond voor branded bevroren snacks. ${ }^{38}$ Deze werden door retailers ook beschouwd als 'must stock'-producten. ${ }^{39}$ Wat betreft aanbodsubstitutie overwoog de Commissie dat producenten van branded producten eenvoudig private label konden maken en dat vrijwel alle producenten van branded ook daadwerkelijk private label produceerden. De Commissie benadrukte wel dat aanbodsubstitutie eenzijdig is omdat private label niet eenvoudig kan overstappen naar branded. Uiteindelijk kwam de Commissie tot de conclusie dat branded en private label tot één gedifferentieerde markt behoren waarin zij tot een bepaalde hoogte concurrentiedruk op elkaar uitoefenen. ${ }^{40}$ De ACM ging ook uit van één relevante markt voor zowel private label als branded snacks, waarbij zij ook met name indirecte concurrentiedruk uit het downstreamniveau overwoog (gezien de symmetrie in het upstreamniveau). ${ }^{41}$

Deze kernoverwegingen en uitgangspunten komen ook tot uitdrukking in de recente Lactalis-zaak, ofschoon de aanpak van de Commissie daar toch enigszins tot discussie kan leiden.
34. CBb 11 februari 2016, ECLI:NL:CBB:2016:23, r.o. 6.2-6.11.

35. T. van Dijk, 'Het CBb komt er uit voor Bolletje-beschuit: ACM bakt het al te bruin', M\&M 2016/5

36. De concentratie werd bij de Commissie gemeld, maar de ACM diende een verwijzingsverzoek in. De Commissie verwees het 'Nederlandse gedeelte' van de concentratie terug naar de ACM en beoordeelde de rest (met name België) zelf.

37. Besluit Commissie 13 januari 2012, zaak COMP/M.6321 (Buitenfood/ Ad van Geloven Holding/JV), punt 30-35

38. Buitenfood/Ad van Geloven Holding/JV, punt 31

39. Buitenfood/Ad van Geloven Holding/JV, punt 32

40. Buitenfood/Ad van Geloven Holding/JV, punt 32-35.

41. Besluit ACM 13 februari 2012, zaak 7313 (Buitenfood - Ad van Geloven - JV), punt 34
Lactalis: de kruisbestuiving van upstream,

downstream en algemene marktoverwegingen?

In een recente zaak inzake Italiaanse kazen (de Lactaliszaak $^{42}$ ) overwoog de Commissie of private label Italiaanse kazen (zoals huismerk Mozzarella) en (A-) merk Italiaanse kazen (zoals Galbani Mozzarella) tot dezelfde relevante upstreammarkt horen. De Commissie liet de exacte definitie van de markt open, maar gaf een soort checklist van tien kernoverwegingen om de relatie tussen private label en branded te beoordelen. Deze tien punten lijken een mengeling van upstream, downstream en algemene marktafbakeningoverwegingen, waarbij men zich kan afvragen of de Commissie het wellicht niet beter had kunnen categoriseren en sommige overwegingen überhaupt had kunnen weglaten.

Punt 1. Een grote meerderheid van de retailers en concurrerende producenten vindt dat branded en private label Italiaanse kazen met elkaar concurreren, maar dat branded producten een (veel) hogere prijs kunnen vragen, zelfs voor producten met zeer vergelijkbare eigenschappen. Aangezien producenten van branded vaak ook private label leveren, geldt het prijsverschil tussen producten ook binnen één en hetzelfde bedrijf. Vanuit de vraagzijde gezien vanuit het oogpunt van de eindconsument zijn branded kaasproducten belangrijk. Ook zijn een aantal branded producten 'must have'-producten vanuit het oogpunt van de retailer. Zo wordt door verschillende retailers aangegeven dat mozzarella van Galbani absoluut must have is, mede omdat het vanuit consumenten wordt gezien als het 'belangrijkste en sterkste merk Italiaanse kazen'. ${ }^{43}$

Punt 2. Branded producten worden geassocieerd met bepaalde standaarden van kwaliteit, verpakking en marketing. Private label wordt doorgaans gezien als een goedkoper alternatief. $^{44}$

Ofschoon indirecte concurrentiedruk - downstreamoverwegingen gezien vanuit het perspectief van de consument - (kan) meespelen bij de vraag of in het upstreamniveau private label en branded met elkaar concurreren, is de vraag of dit tweede punt wel in een checklist voor het upstreamniveau thuishoort (vooral aangezien het in overige punten (wordt gedekt). Men zou zich kunnen voorstellen dat punt 1 en 2 samengevoegd zouden worden en door de Commissie aangemerkt zouden worden als de downstreamoverwegingen die relevante indirecte concurrentiedruk uitoefenen in het upstreamsegment.

Punt 3. Ook de privatelabelkant van de markt is gedifferentieerd door verschillende niveaus van kwaliteit, verpakking enzovoort: bijvoorbeeld het instapniveau met simpelere verpakking en een duurder niveau met mooiere en kwalitatievere verpakking. ${ }^{45}$

\footnotetext{
42. Besluit Commissie 9 december 2019, zaak COMP/M.9413 (Lactalis/ Nuova Castelli)

43. Lactalis/Nuova Castelli, punt 82-84.

44. Lactalis/Nuova Castelli, punt 85 .

45. Lactalis/Nuova Castelli, punt 86.
} 
De Commissie lijkt hiermee aan te geven dat een eventuele segmentering tussen premium- en non-premiumproducten binnen private label relevant is voor de vraag of (een deel van) private label met branded concurreert. Zo concurreert private label vermoedelijk beter met branded als er verschillende 'kwaliteitsniveaus' binnen private label zitten, dus bijvoorbeeld een premiumniveau dat meer gelijkenissen vertoont met de branded producten. De vraag blijft dan alsnog of indien het privatelabelsegment slechts bestaat uit één kwaliteitsniveau, er dan (per definitie) minder concurrentie vanuit de privatelabelproducten zou uitgaan op de branded producten.

Daarnaast kan men zich ook afvragen of de beoordeling of er aparte productmarkten voor 'premium'- en 'basic'producten moeten worden onderscheiden niet voorafgaat aan de beoordeling of binnen die submarkten weer aparte submarkten voor private label en branded moeten worden onderscheiden. Zó ging de Commissie althans te werk in de McCain/Lutosa-zaak waar zij een onderscheid tussen premium- en non-premiumaardappelproducten overwoog. Vervolgens werd gekeken of er concurrentiedruk van privatelabelproducten binnen beide segmenten bestond.

Punt 4. Het afnemen van branded en privatelabelproducten geschiedt anders; branded door middel van bilaterale onderhandelingen tussen retailer en merkeigenaar, en private label via tenders uitgeschreven door de retailer. Omdat de privatelabelproducent niet hoeft te investeren in marketing en naamsbekendheid, zijn toetredingsbarrières voor producenten minder hoog. Daarnaast zijn switchingdrempels voor retailers laag bij privatelabelproducten. ${ }^{46}$

Punt 5. Ofschoon er differentiatie bestaat in prijzen, merk en producteigenschappen, bestaat er mogelijk wel een 'continuüm' van keuzes voor de consumenten. Hierdoor zou er vervolgens weer een substitutieketen bestaan. Zo lijkt uit de tenderdocumenten die de Commissie heeft ingezien dat bepaalde privatelabelalternatieven worden uitgekozen op gelijkenis met de branded producten. ${ }^{47}$

Wederom kan men zich afvragen of deze overweging niet een algemener punt van marktafbakening is. Zoals de Commissie beschrijft in haar bekendmaking inzake de bepaling van de relevante markt, ${ }^{48}$ kan in bepaalde gevallen het bestaan van substitutieketens leiden tot de bepaling van een relevante markt waarop producten die zich aan de uiteinden van de markt bevinden, niet rechtstreeks substitueerbaar zijn. ${ }^{49}$ Uiteindelijk zal de vraag zijn of product $B$ aan de vraagzijde een substituut is voor producten $\mathrm{A}$ en $\mathrm{C}$. Zelfs indien de producten $\mathrm{A}$ en $C$ geen directe substituten aan de vraagzijde zijn,

46. Lactalis/Nuova Castelli, punt 87-88.

47. Lactalis/Nuova Castelli, punt 89 en voetnoot 121.

48. Bekendmaking van de Commissie inzake de bepaling van de relevante markt voor het gemeenschappelijke mededingingsrecht.

49. Bekendmaking van de Commissie inzake de bepaling van de relevante markt voor het gemeenschappelijke mededingingsrecht, punt 57. kunnen zij in dezelfde relevante productmarkt vallen, aangezien hun respectievelijke prijsstelling beperkt kan zijn wegens het risico dat hun afnemers op product $B$ overschakelen. ${ }^{50}$

Men kan zich dan afvragen, of er bijvoorbeeld enerzijds een markt bestaat voor premium (buffel)Mozzarella en anderzijds een markt voor basic Mozzarella, en daarbinnen vervolgens weer een onderscheid kan worden gemaakt tussen private label of branded. De vraag blijft namelijk of er een kwaliteitscontinuüm bij privatelabelproducten bestaat omdat branded een dergelijk kwaliteitscontinuüm heeft, of omdat er een (quasi)aparte vraag naar is.

Punt 6. De verschillende manieren om privatelabel- of branded producten af te nemen zijn niet voldoende om te onderbouwen dat de prijsdynamiek tussen de verschillende producten substantieel anders is. De Commissie overweegt vervolgens dat er mogelijk prijsverhogingen zouden kunnen ontstaan in een aparte markt voor branded als een concentratie zou leiden tot mededingingsbezwaren in een privatelabelmarkt. Volgens de Commissie is dit omdat er in de on the shelf-concurrentie (dus in de verkoop aan consumenten) een concurrentieel effect ontstaat; private label wordt immers duurder. Dit kan dan weer als gevolg hebben dat branded producenten hun kans zien om prijzen voor de branded producten in de upstreammarkt te verhogen. ${ }^{51}$

De vraag is hier of dit niet eerder een punt van de concurrentieanalyse is, in plaats van een overweging inzake marktafbakening. Zo geeft de Commissie zelf ook aan dat als er aparte markten zouden zijn voor private label en branded in het upstreamniveau, een prijsverhoging van privatelabelproducten in het upstreamniveau de concurrentie in het downstreamniveau kan beinvloeden waardoor de producenten van branded ook hun kans zien om hun prijzen in het upstreamniveau te verhogen. Dit lijkt dan ook eerder een overweging ten aanzien van de effecten van de concentratie op de relevante (en aangrenzende) markten en niet zozeer een onderscheidende overweging ten aanzien van private label en branded.

Punt 7. Interne stukken van partijen tonen aan dat zij zowel privatelabel- als branded producten in de gaten houden en marktaandelen van beide bijhouden.

Punt 8. De meldende partij gaf aan dat zij privatelabelproducten in acht neemt bij het opstellen van bedrijfsstrategie en marketingplannen voor haar branded producten (om zo geen marktaandeel te verliezen aan privatelabelproducten). Daarnaast volgt uit de interne stukken van partijen dat private label Italiaanse kazen recent een opmars hebben gemaakt en een relatief groot marktaandeel hebben weten te verkrijgen.

Punt 9. De meeste (zo niet alle) producenten van branded Italiaanse kazen maken ook privatelabelproducten.

50. Bekendmaking van de Commissie inzake de bepaling van de relevante markt voor het gemeenschappelijke mededingingsrecht, punt 57.

51. Lactalis/Nuova Castelli, punt 90. 
Aangezien de productiefaciliteiten voor privatelabel- en branded producten hetzelfde zijn, kunnen producenten makkelijk switchen van het ene product naar het andere.

Punt 10. Voor producenten die zich met name richten op branded Italiaanse kazen, zijn privatelabelbestellingen zeer belangrijk omdat die een idee geven over de waarde van ongebruikte capaciteit. Derhalve, overweegt de Commissie, heeft een verschuiving in de verkoop van privatelabelvolumes van een producent die zich met name richt op branded producten een effect op zijn bezettingsgraad en als zodanig kan dat een verandering teweegbrengen in de algehele kostenstructuur van zijn producten.

Punten 9 en 10 lijken hetzelfde punt te adresseren, namelijk een beoordeling van de concurrentiesymmetrie.

De Commissie lijkt met haar tien kernoverwegingen in de Lactalis-zaak toch enige mate van verwarring te zaaien. Dit geldt dan met name voor de overwegingen waarvan kan worden gezegd dat dit juist algemene marktoverwegingen (punten 3 en 5), of de overwegingen die alvast in detail treden op de concurrentieanalyse en in mindere mate de afbakening van de relevante markt (punt 6).

Naast de analyse of private label en branded tot dezelfde markt behoren, wordt steeds vaker overwogen hoe copacking binnen dit verhaal past.

\section{Co-packing: de vreemde eend in de bijt?}

Tot op heden zijn er niet veel beschikkingen waarin de Commissie, de ACM of de CMA in detail co-packingmarkten moesten beoordelen. Wel zijn er twee vergelijkbare zaken waar de Commissie en de CMA naar hebben gekeken. Eerst heeft de Commissie een overname door Refresco van Pride Foods beoordeeld, en vervolgens heeft de CMA een overname door hetzelfde Refresco van Cott Corporation Inc (Cott) beoordeeld. Ze komen uiteindelijk tot verschillende conclusies wat betreft marktafbakening.

In een beschikking uit eind 2013 beoordeelde de Commissie de fusie tussen het Nederlandse Refresco, een bottelaar gespecialiseerd in de productie van privatelabel- en merkproducten via co-packing (die zelf ook branded produceert), en het Britse Pride Foods, ook een bottelaar gespecialiseerd in de productie van privatelabel- en merkproducten via co-packing (die eveneens zelf ook branded produceert). In 2017/2018 beoordeelde de CMA in een vergelijkbare zaak de overname door hetzelfde Refresco van Cott. Ook in deze zaak waren partijen beide actief in de productie van private label, merkproducten via co-packing en eigen branded producten. In beide zaken bestond tussen partijen dus volledige concurrentiesymmetrie op het upstreamniveau.
Toch kwam de Europese Commissie tot een andere marktafbakening dan de CMA. Waar de Commissie concludeerde dat er aparte markten zijn voor private label en co-packing, komt de CMA tot de conclusie dat één relevant markt bestaat voor de productie voor derden (dus private label en co-packing).

In beide zaken voerde Refresco (en respectievelijk Pride Foods en Cott) aan dat er in ieder geval geen nader onderscheid moest worden gemaakt tussen productie van private label en co-packing. In de Commissiezaak voerde Refresco zelfs aan dat al het bottelen van diverse niet-alcoholische dranken tot dezelfde markt behoorde met als voornaamste argument dat private label en branded met elkaar concurreren op zowel prijs als schapruimte - met andere woorden dat er substantiële indirecte concurrentiedruk uit het downstreamniveau plaatsvindt gezien de symmetrie upstream. ${ }^{52}$ Indien de Commissie deze voorgestelde marktafbakening niet zou accepteren, zou er volgens partijen in ieder geval een relevante productmarkt bestaan voor de productie voor derden, dus private label en co-packing ${ }^{53}$ (met andere woorden de markt die ook de CMA overwoog).

Ofschoon het marktonderzoek van de Commissie uitwees dat vanuit een aanbodzijde dezelfde machines kunnen produceren en bottelen voor branded en privatelabelproducten, bleek er een aparte vraag te zijn voor private label en co-packing. De Commissie benadrukte dat retailers zowel branded als private label nodig hebben op hun schappen, maar dat beide markten volgens een (volledig) andere dynamiek opereren. In tegenstelling tot de Commissie bakende de CMA hier één aparte markt af voor de productie van privatelabelproducten en merkproducten via co-packing ${ }^{54}$ omdat uit het marktonderzoek bleek dat de productieprocessen identiek zijn en concurrentieparameters ook hetzelfde waren (lees 'competitive conditions do not vary materially' [cursivering toegevoegd]). Met andere woorden, zelfs als er al verschillen zouden bestaan tussen productie voor private label of co-packing, dan hebben die geen materiële verschillen en dus geen materiële impact op de vraag of het een (materieel) andere marktactiviteit is. De CMA oordeelde dat er daarom nagenoeg geen verschil zou zijn in de beoordeling van private label en co-packing.

Zowel de Commissie als de CMA overwoog dat de eigen productie van branded producten moest worden uitgesloten van de markt omdat deze productieactiva niet beschikbaar waren om te produceren voor derden. ${ }^{55}$

Dat de Commissie branded uitsloot - dat wil zeggen de eigen productie van merkproducten - valt nog te volgen, maar dat de Commissie co-packing als aparte markt afbakende, is lastiger. Temeer omdat de Commissie hier onder andere een belangrijke downstreamoverweging aan ten grondslag legt, terwijl het om de upstreammarkt

52. Besluit Commissie 4 oktober 2013, zaak COMP/M.6924 (Refresco Group/Pride Foods), punt 41.

53. Refresco Group/Pride Foods, punt 42.

54. Besluit CMA 3 januari 2018, zaak ME/6705/17 (Refresco Group N.V./ Cott Corporation Inc.), punt 32.

55. Refresco Group/Pride Foods, punt 44 en Refresco Group N.V./Cott Corporation Inc., punt 27-32. 
gaat. Zo geeft de Commissie aan dat (1) retailers beide producten (de privatelabelproducten en branded producten) op hun schappen nodig hebben, en (2) beide markten (volledig) anders opereren, want andere contractduur, andere literprijs, ander tenderproces, enzovoort. Dit roept een aantal vragen op, mede gelet op de marktafbakening van de CMA.

\section{Ad (1) Retailers hebben zowel private label als} branded nodig

Deze overweging lijkt niet onmiddellijk relevant voor de vraag of co-packing en private label in dezelfde markt concurreren. Consumenten weten immers doorgaans niet of een merk in eigen productie wordt gemaakt of bij een derde wordt geproduceerd. Deze pure downstreamoverweging lijkt dan ook met name betrekking te hebben op de vraag of branded en private label met elkaar concurreren, maar die sluit de Commissie überhaupt al uit (vgl. punt 44 'eigen productie dient te worden uitgesloten want die activa zijn niet beschikbaar voor de productie voor derden' ${ }^{56}$ ). De CMA besteedt hier bijvoorbeeld geen aandacht aan in haar beoordeling van de upstreammarkt, waar zij ervan uitgaat dat er upstreamvraag is naar zowel private label als branded (uiteraard een afgeleide uit het downstreamniveau), maar dat de concurrentieparameters tussen de productie van privatelabelof merkproducten via co-packing upstream nagenoeg niet verschillen.

De vraag is of, en zo ja in welke hoedanigheid, de Commissie de 'aparte vraag' heeft laten meewegen in haar analyse van de upstreammarkt ten aanzien van private label en co-packing (niet branded in eigen productie). Is de Commissie bijvoorbeeld nagegaan of retailers een aparte vraag hadden voor branded producten gemaakt door de merkhouders zelf of gemaakt door derden? Het lijkt niet voor de hand te liggen dat retailers daar een onderscheid in zouden maken.

Wellicht heeft de Commissie bedoeld dat er een aparte vraag is naar private label, namelijk met retailers als klant, en co-packing, namelijk met merkhouders als klant. Dat daar een verschil in bestaat, lijkt evident. Maar de vraag blijft dan alsnog of deze aparte vraag cruciaal is voor de marktafbakening gezien de identieke productieprocessen en aanbodsubstitutie, de identieke vraag van de eindklant in het upstreamniveau, namelijk de retailer die zowel private label als branded (ongeacht hoe die wordt geproduceerd) nodig heeft.

Ad (2) Beide markten opereren anders

In dezelfde zin waarin de Commissie overweegt dat retailers beide producten (lees branded en private label) op hun schappen nodig hebben, geeft zij aan dat beide markten (volledig) anders opereren onder verwijzing naar contractduur, tenders, risico en verantwoordelijkheden. De CMA overweegt juist dat er geen materiële verschillen zijn in de concurrentiële context tussen private label en productie van merkproducten via copacking. ${ }^{57}$

56. Refresco Group/Pride Foods, punt 44.

57. Refresco Group N.V./Cott Corporation Inc., punt 27-32.
Wederom kan men zich hier afvragen of de Commissie branded en co-packing niet verwart en of deze overweging wel zo relevant is voor de upstreambeoordeling van co-packing en private label.

Wat betreft risico en verantwoordelijkheden functioneren private label en co-packing namelijk vrijwel hetzelfde: een producent produceert op aanvraag voor een merkhouder of retailer. Die draagt vervolgens het merkrisico en de verantwoordelijkheid voor de afzet van het product. Ofschoon de CMA verwijst naar een eerdere zaak (de Cott/Macam-zaak) waarin uit haar marktonderzoek bleek dat er bepaalde eigenschappen en elementen zijn in de vraag naar co-packing die anders zijn dan bij private label (zo noemt de CMA bijvoorbeeld additionele diensten die de producent dan kan aanbieden zoals R\&D of marketing), ${ }^{58}$ concludeert zij dat er geen materiële verschillen zijn in de concurrentiële context. ${ }^{59}$

Wat betreft tenders functioneren private label en copacking vaak hetzelfde, doorgaans via tenders georganiseerd door retailers dan wel merkhouders en soms met bilaterale onderhandelingen. Wat betreft de contractduur is het goed denkbaar dat daar nog een verschil in zit: private label heeft vaak contracten van slechts één jaar of enkele jaren ${ }^{60}$ terwijl bij co-packing dat vaak iets langer is (bijv. vijf à tien jaar), maar dit enkele verschil lijkt niet voldoende om het als aparte markt af te bakenen (wederom: er is geen materieel verschil). Uiteindelijk zijn de kernprincipes van het produceren voor een derde hetzelfde.

Een nuttige parameter om wellicht te overwegen in het kader van marktafbakening was hoe producenten die voornamelijk voor derden produceren (zoals de fuserende partijen destijds) met extra/overcapaciteit omgingen. Werd er specifieke capaciteit gereserveerd voor private label? Of voor co-packing? Of werd dit door elkaar gebruikt, gezien de identieke productieprocessen? Waar de Commissie dit wel doet voor eigen productie (van branded), laat zij dit dus na bij private label en copacking. De CMA daarentegen gaf aan dat marktaandelen in dit soort markten slechts beperkte waarde hebben en het onderzoek van de CMA spitste zich dan ook toe op de vraag of er voldoende alternatieve aanbieders zouden overblijven die geloofwaardig zouden kunnen meedingen naar toekomstige projecten. ${ }^{61} \mathrm{Er}$ werd onder andere kritisch gekeken naar het gebruik van capaciteit en met name rest/overcapaciteit. Ofschoon dit in het besluit met name terugkomt als een overweging in de concurrentiële analyse, lijkt het logisch dat de CMA dit ook heeft meegenomen in haar marktafbakening althans dat dit een rol speelde.

In zaken waar co-packing aan de orde komt, lijkt het lastig om één manier te vinden om marktmacht van partijen goed in kaart te brengen, en zal het vaak uitkomen op een combinatie van factoren en overwegingen die daaraan ten grondslag liggen. Zoals de CMA

\footnotetext{
58. Refresco Group N.V./Cott Corporation Inc., punt 29.

59. Refresco Group N. V./Cott Corporation Inc., punt 27-32.

60. Vgl. Refresco Group/Pride Foods, punt 82.
}

61. Refresco Group N.V./Cott Corporation Inc., punt 74 
opmerkt, zijn marktaandelen slechts beperkt nuttig bij het beoordelen van de relatieve marktmacht van partijen en concurrenten en draait het meer om de beschikbare capaciteit. Het is overigens ook niet evident om marktaandelen in kaart te brengen; moet de afzet van het merk aan de merkhouder of co-packer worden toegerekend? Dit zal vermoedelijk afhankelijk zijn van de upstreamactiviteiten van partijen. Bij een fusie tussen twee copackers zal men geneigd zijn de afzet van de producten aan de co-packers toe te rekenen (temeer indien deze nog lange contracten voor deze productie hebben). Bij een fusie tussen twee merkhouders zal men geneigd zijn de afzet van producten aan de merkhouders toe te rekenen. Maar bij een fusie tussen een merkhouder en een co-packer is dit lastiger, alhoewel een dergelijke analyse zich voornamelijk zal toespitsen op de verticale relatie en mogelijke bron- en klantafschermingsrisico's. Bij een fusie tussen een producent van private label en een producent van co-packing is marktafbakening dan weer doorslaggevend (indien er aparte markten zijn, is er immers geen overlap).

\section{Conclusie}

De beschikkingspraktijk van de Commissie, de ACM en de CMA inzake branded, private label en/of co-packing is sterk casuïstisch. Dezelfde overwegingen liggen doorgaans ten grondslag aan de verschillende beschikkingen. Systematisch wordt een onderscheid gemaakt tussen het upstreamniveau en het downstreamniveau, en binnen het upstreamniveau nog tussen meerdere segmenteringen. Hierbij is de belangrijkste overweging of er sprake is van concurrentiesymmetrie tussen partijen, en vervolgens hoe de indirecte concurrentiedruk uit het downstreamniveau doorwerkt in het upstreamniveau.

Gezien de beperkte beschikkingspraktijk op het gebied van co-packing zal het met name interessant zijn of en welke ontwikkelingen zich hier nog verder gaan afspelen. Zoals hierboven genoemd zijn er twee betrekkelijk vergelijkbare zaken (de Refresco-zaken), waarin de beoordeling door enerzijds de CMA en anderzijds de Commissie echter tot twee zeer verschillende uitkomsten leidt: namelijk één relevante markt voor de productie voor derden (dus zowel private label als co-packing) en twee aparte markten voor (1) de productie van private label, en (2) de productie van branded via copacking.

Is marktafbakening bij branded, co-packing of private label slechts een kwestie van smaak? Uiteindelijk liggen dezelfde overwegingen en uitgangspunten ten grondslag aan het antwoord hierop, en zal het dus per zaak anders liggen. 